\title{
THE LEGAL FRAMEWORK FOR ISLAMIC BANKING AND THE QUEST FOR FINANCIAL INCLUSION IN NIGERIA
}

\author{
Umar Sani Bebeji ${ }^{1}$ \\ Hussaini Bala ${ }^{2}$ \\ Hassan Bala ${ }^{3}$
}

\begin{abstract}
The legal framework for Islamic banking is incoherent and in some cases, vague. The laws do not contemplate the fundamental conditions required for Islamic banking to thrive, as they have been originally designed to suit conventional banking. This study utilizes document analysis technique, Islamic jurisprudence and Nigerian laws to examine the legal framework for Islamic banking and the quest for financial inclusion in Nigeria. Similarly, policy initiatives to promote financial inclusion through Islamic finance seem half-hearted in design and overly cautious in implementation. It is observed that conventional banking has not really worked in the best interest of Nigerians, especially in securing loans for investments. In fact, it's over-reliance on interest, loose prudential guidelines and its general capitalistic foundations have brought it into collision with the Islamic and customary principles of communality as against individuality known in Nigeria. Securing loans for investments comes with
\end{abstract}

1 Lecturer, Department of Commercial Law, Faculty of Law, Ahmadu Bello University, Zaria, umarbebeji@yahoo.co.uk

2 Lecturer, Department of Accounting, Faculty of Management Science, Kaduna State University, Nigeria, hussainumi2013@gmail.co

3 Lecturer, Department of Private Law, Faculty of Law, Ahmadu Bello University, Zaria, umarbebeji@yahoo.co.uk 
cut-throat conditions, riddled with cases of fraudulent and sharp practices that significantly erode of the customers. Islamic finance, on the other hand, promotes economic growth through its developmental and social benefit focus and more equitable contracts. It also presents an opportunity to harness the money held outside the financial system due to the avoidance of interest and serves as a major factor required to bridge. What will be required is comprehensive legislation by the National Assembly to address this concern, and to also put to rest the recurring assault on the guidelines issued by the CBN on Islamic banking. This is what obtains in countries like Malaysia, United Arab Emirates, Germany and Uganda.

Keywords: legal framework, Islamic Law, financial inclusion

\section{INTRODUCTION}

The world economy has gradually come to rely greatly on the modern banking system. The banking system dictates the pace of economic growth as it performs the basic function of financial intermediation between those with savings to spare and those looking for funds to invest in various ventures. In doing this, the bank negotiates interests for itself (and its investors) and depositors as the primary means of making a profit.

Nigeria has a total population of about 198 million. ${ }^{4}$ More than half of this number is adults who do not have access to financial services, showing that Nigeria is, in fact, lagging in financial inclusion when compared to its peers across Africa. ${ }^{5}$ A survey conducted in Nigeria in 2008 by Enhancing Financial Innovation and Access (EFInA) revealed that about $53.0 \%$ of adults were excluded from financial services. However, this rate dropped to $46.3 \%$ in $2010 .{ }^{6}$ As a result, various policies targeted at financial inclusion have so far

4 According to National Population Commission (NPC), 'Nigeria's current population is put at 198 million people', http://population.gov.ng/, accessed on 16 March 2018.

5 Van de Walle, N., Wanga, C. Sahai, R., 'Why is Nigeria's Financial Inclusion Lagging Compared to Its African Peers?,' http://finclusion.org/blog/fii-updates/ why-is-nigerias-financial-inclusion-lagging-compared-to-its-african-peers.html, accessed on 3 February 2018.

6 Enhancing Financial Innovation \& Access (EfinA), 'Access to Financial Services in Nigeria: 2010's Survey (2010), www.EfinA.org.ng, accessed on 12 February 2018. 
not had the desired impact on the economy due to lack of access to finance. ${ }^{7}$ But what is more profound and largely ignored is the prohibition of interest placed on the Muslims that has accounted for restraints over the years. A study found that Muslims are less likely to have bank accounts than non-Muslims, partly for religious reasons and partly because of discrimination. ${ }^{8}$ The idea of Islamic banking appears to have been designed specifically to rectify this imbalance as a system of banking that is devoid of interest and consistent with the principles of Islamic commercial jurisprudence. It prohibits the accretion of interest to both depositors and the bank ${ }^{9}$ and is fast being accepted as a reliable alternative to conventional banking, all over the world. ${ }^{10}$

The aim of this paper, therefore, is to address concerns of financial exclusion as it relates to the unambiguous prohibition of banking interest on Muslims ${ }^{11}$ and to appraise the legal framework for Islamic banking in Nigeria. To achieve this, the paper is designed to analyse the status of interest in Islam, the historical development of Islamic banking and its regulation, tracing the constitutional basis for the adherents of the Islamic faith to engage in economic activities compatible with their religious beliefs; the status of interest in Islamic jurisprudence and the quest for financial inclusion and the prospects of Islamic banking and finance in Nigeria. This will be done while also attempting to dispel some of the criticisms put forward in opposition to Islamic banking in Nigeria. The paper will wrap up with recommendations on the future of Islamic banking in Nigeria.

7 Aro-Gordon, S., 'Effectiveness of Financial Inclusion Strategy in Nigeria', (Paper presented, 2nd International Conference on Inclusive Economic Growth and Sustainable Development, Mysuru, India, 18-19 November 2016), 2.

8 Beck, T. \& Brown, M., 'Which Households Use Banks? Evidence from the Transition Economies,' European Central Bank Working Paper Series, No. 1295 (2011): 4-32. There is also another finding that Muslims are less included in the formal financial system than non-Muslims the world over. Demirgic-Kunt, A., Klapper, L. \& Randall, D., 'Islamic Finance and Financial Inclusion: Measuring Use of and Demand for Formal Financial Services among Muslim Adults,' The World Bank Policy Research Working Paper 6642 (2013).

9 Ajagbe, T. S. \& Brimah, A. N., 'Islamic Banking Development and Evolution: Current Issues and Future Prospects,' Journal of Research in International Business and Management, vol. 3/2 (2013): 74.

10 Islamic finance, which dates back to 1975 with the establishment of Bank Faisal in Egypt. See Oyeniran, B., 'Can Islamic Banking Work in Nigeria?' Journal of Sustainable Development in Africa, vol. 14/2 (2012): 25.

11 A variant of ribāa, explicitly prohibited in the al-Qur'ān, the Sunnah of the Holy Prophet (SAW) and by consensus of Muslim Jurists. 


\section{THE STATUS OF INTEREST IN ISLAM}

Islamic finance generally is a system of finance that carries its services and activities based on the tenets of Islamic commercial jurisprudence. It is an engagement in $M u$ 'àmalat (Islamic transactions) which comprises of banking business, trading, investments and commercial activities, as well as the provision of financial products and services in accordance with the principles of Shariah. ${ }^{12}$ Islam is a complete way of life that demands total submission the will of Allah (SWT) in the al-Qur' 'àn. It has a complete code consisting express instructions of Allah (SWT) as expounded by Prophet Muhammad (SAW) in the Sunnah. Economic activities are originated and linked with religious activities, which are either halal (permissible) or haram (prohibited). ${ }^{13}$ The conventional banking system thrives under the principle of interest, a category of usury ( $r i b \bar{a})$, expressly prohibited by all sources of Shariah: the al-Qur'ann, Sunnah, ijm $\bar{a}^{\circ}$ (consensus of Muslim Jurists) and qiyās (analogical reasoning).

The word $r i b \bar{a}$, in the Arabic language, literally means an "increment" or "addition". In Islamic jurisprudence, the term rib $\bar{a}$ has a special meaning. It is an unjustified increment in borrowing or lending money, paid in kind or in money above the amount of loan, as a condition imposed by the lender or voluntarily by the borrower. Ribā defined in this way is called in fiqh riba alduyūn (debt usury). ${ }^{14}$ Certainly, this is the category referred to as interest in conventional banking. In the al-Qur'ān Allah (SWT) declared:

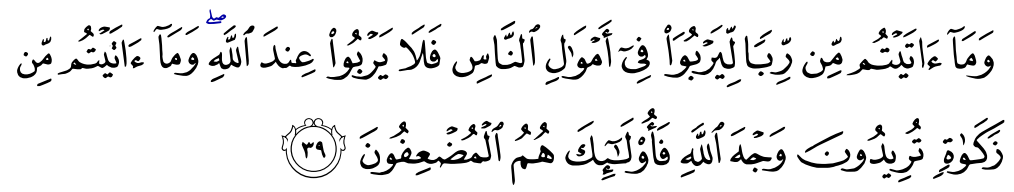

"That which ye given in ribā in order that it may increase on (other) people's property hath no increase with Allah, but that

12 Chiroma, M. \& Sandabe K.B, Abdullahi, M.A. \& Haseeb A., 'Legal Framework Regulating Islamic Finance in Nigeria: A Critical Appraisal of Hurdles against the Effective Shari'ah Governance,' Unimaid Journal of Private and Property Law, vol. 1/1 (2016): 231.

13 Ahmad, A., Kashif-ur-Rehman \& Humayoun A. A., 'Islamic Banking and Prohibition of Riba/Interest,' African Journal of Business Management, vol. 5/5 (2011): 1763.

14 Ahmad, A.R.Y., 'Riba, Its Economic Rationale and Implications,' Institute of Islamic Banking and Insurance, Islamic University Pakistan, http://www.islamicbanking.com/iarticles_8.aspx, accessed on 5 March 2018. 
which ye give in charity; seeking Allah's countenance, hath increase manifold".

Similarly, He (SWT) emphasised:

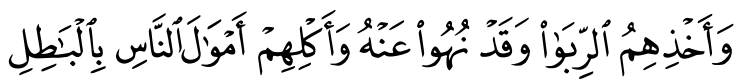

"That they took ribā, though they were forbidden; and that they devoured men's substance wrongfully."

(Surah al-Nisā', 4: 161)

This clearly acknowledges that rib $\bar{a}$ as practised by the people in Arabia before the coming of Islam. ${ }^{15}$ To further underscore the prohibition of rib $\bar{a}$, Allah (SWT) enjoins all his servants to stay away from it, in the following words:

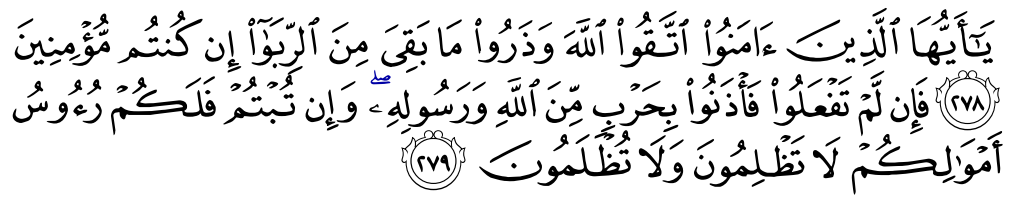

"O ye who believe, fear Allah and give up what remains of your demand for usury if ye are indeed believers. If ye do not, take notice of war from Allah and His messenger: but if ye turn back, ye shall have your capital sums; deal not unjustly, and ye shall not be dealt with unjustly." 16

(Surah al-Baqarah, 2: 278-279)

Clearly, Allah (SWT) rejects the increase that manifests as ribā and warns the people against it. This reminds us that our life is just a journey to eternity and therefore what should matter most is the accumulation of Allah's pleasure and not the accumulation of wealth through unethical means. ${ }^{17}$ The pervasive nature of $r i b \bar{a}$ in modern finance was predicted by the Prophet (SAW) himself. In this regard, Abu Hurayrah (RA) narrated that the Holy Prophet (SAW), said:

15 Ahmad, A., Kashif-ur-Rehman \& Humayoun A. A., 'Islamic Banking and Prohibition of Riba/Interest,' 1764.

16 The prohibition is further supported by various chapters of the holy al-Qur'ān, like Surah al-Baqarah, 2: 275 and chapters 3:130 and 2: 281.

17 Ahmad, A., Kashif-ur-Rehman \& Humayoun A. A., 'Islamic Banking and Prohibition of Riba/Interest,' 1764. 


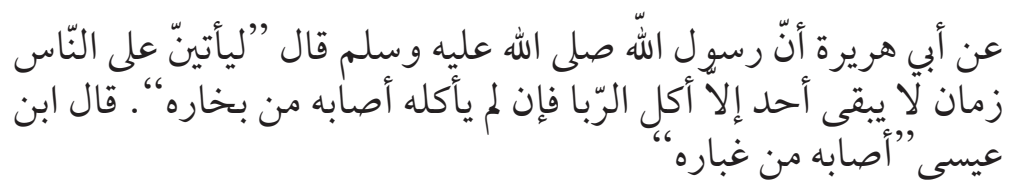

"Narrated Abu Hurayrah: The Prophet SAW said: A time is certainly coming to mankind when only the receiver of usury will remain, and if he does not receive it, some of its vapour will reach him. Ibn Isā said: Some of its dust will reach him." 18

To warn against it, he also narrated that the Prophet (SAW), said:

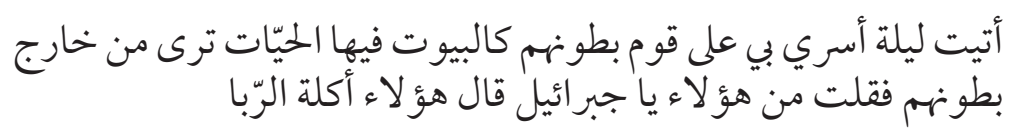

"On the night of Ascension I came upon people whose stomachs were like houses with snakes visible from the outside. I asked Gabriel who they were. He replied that they were people who had received interest." 19

Muslim Jurists are also unanimous on the prohibition of riba . The efforts by some modern scholars to distinguish between rib $\bar{a}$ and bank interest in order to craftily legitimize the latter was met with universal rejection and contempt. ${ }^{20}$ This accounts for the refrain, reservations, and later, agitations for Islamic banking in Nigeria as a way of providing a halal ${ }^{21}$ alternative.

\section{ORIGIN AND DEVELOPMENT OF ISLAMIC BANKING IN NIGERIA}

Before colonialism, traditional societies engaged in a diverse range of commercial and financial relations based on Islamic law - the Shariah, predominantly in the North, and customary practices predominantly in the South, as developed from the peoples' consciousness. Muslims did not transact

18 Abī Dāwud, Sulayman Ibn al-Ash'ath al-Sijistānī al-'Azdī, Saḥ̄h Sunan Abī Dāwūd (Riyāẹ: Dār al-Salām, 1998), 465, "Kitāb al-Buyū', Bāb fì Ijtinabi alShubuhāt, hadìth no. 3322.

19 Ibn Mājah, Abū 'Abd Allāh Muhammad Ibn Yazīd al-Qazwinī, Sunan Ibn Mājah (Riyāụ: Dār al-Salām, 1984), 790, "Kitāb al-Tijarat, Bāb al-Taghlīz fī al-Ribā, hadìth no. 2359.

20 Siddiqi, M.J., 'Issues in Islamic Banking,' Economic Series, vol. 4 (Leicester, Islamic Foundation, 1983), 9.

21 Halal is an Arabic word meaning lawful or permitted by Allah. Siddiqi, M.J., 'Issues in Islamic Banking,' 9. 
in usury (the base of modern banking) and other practices prohibited by Islam. ${ }^{22}$ This did not hinder transactions or defer economic development as transSaharan trade boomed across the region. The coming of colonial masters and the subsequent introduction of what is now known as conventional banking put the Muslim population in a flux: whether to participate in a system anchored on expressly prohibited principles or refrain from taking part. Meanwhile, in the 1940s, some young economists theorised how the principles of Islamic commercial jurisprudence could guide the operations of banks to finance themselves without charging or taking interest based on halal transactions. ${ }^{23}$ After a series of "trial and errors", came the breakthrough in the 1970s when the rapid establishment of Islamic banks dominated the Muslim World. ${ }^{24}$

As far back as independence, an attempt was made at venturing into Islamic banking by establishing Nigeria Muslim West Africa Bank Ltd. ${ }^{25}$ However, shortly after its establishment the then Federal Minister of Finance, Chief Obafemi Awolowo ordered it to stop operations on the ground that it was not categorically licensed to operate as an Islamic bank. ${ }^{26}$ No doubt the current pedestal upon which Islamic banking regulation rests on is the Banks and Other Financial Institutions Decree (BOFID). ${ }^{27}$ Particularly, the proviso of section 23(1) made some rather vague reference to the existence of this kind of bank, thus it states:

"Every bank shall display at its offices its lending and deposit interest rates and shall render to the Bank information on such rates as may be specified, from time to time, by the Bank;

22 Alkali, M.B., \& Buang, A.H., 'Challenges in Implementing Islamic Banking and Finance in Nigeria: A Legal Insight,' Jurnal Syariah, vol. 23/1 (2015): 145.

23 This stage Began in the early 1900s and marked by the writings of Abul A'ala Maududi (1937), Hassan Al-Banna (1939), Hafiz Al-Rahman (1942), Muhammad Hamidullah (1944), Anwar Qureshi (1946), Naiem Siddiqi (1948), and Mohammad Yousuf Al-Dean (1950). See Ali, S. S., Modern Challenges to Islamic Banking (Cambridge: Cambridge University Press, 2016).

24 Alharbi, A., 'Development of the Islamic Banking System,' Journal of Islamic Banking and Finance, vol. 3/1 (2015): 12.

25 Zubair, A. \& Alaro, A. A., 'Legal and Operational Frameworks of Islamic Windows in Conventional Financial Institutions: Nigeria as a Case Study,' (Paper presented, 1st University of Ilorin International Conference on Islamic Bank and Finance, Jointly Organized by Department of Islamic Law, UNILORIN and Islamic Research and Training Institute, Jeddah, Saudi-Arabia, 6-8 October 2009).

26 It was in 1968 that the Federal Government revoked its license to carry on banking business in Nigeria. See Muslim Bank (Revocation of License) Order, 1968.

27 Now Banks and other Financial Institutions Act (BOFIA). 


\section{"Provided that the provisions of this subsection shall not apply to profit and loss sharing banks (emphasised)." 28}

Based on this the CBN granted a license to the defunct Habib Bank Plc. ${ }^{29}$ to commence operations as a "window", under the principle of PLS in 1992 but the bank could not commence operations until 1994, ${ }^{30}$ and by 1996 the bank secured its final approval. In January 2009, the Central Bank of Nigeria joined the Islamic Financial Services Board (IFSB) as a full-fledged member. Later, the Central Bank issued a draft framework for the regulation and supervision of non-interest banks in Nigeria as an exposure document to elicit comments and suggestions from stakeholders. As a result, the framework was re-issued on June 21, 2011, offering two forms of Non-Interest Financial Institutions (NIFIs): NIFIs based on principles of Islamic commercial jurisprudence, and NIFIs based on any other established rules and principles.

Nigeria was later to join the Islamic Liquidity Management Corporation (ILMC) in 2010, through the CBN, along with 11 other Central Banks and two multilateral organisations. ${ }^{31}$ It was this atmosphere that led to the establishment of the first full-fledged noninterest bank: Jaiz Bank Plc, which commenced operations as a regional bank in January 2012, in Abuja, Kano and Kaduna. ${ }^{32}$

\section{THE QUEST FOR FINANCIAL INCLUSION MEETS CRAVINGS FOR ISLAMIC FINANCE}

Financial inclusion is not just peculiar to Nigeria but a global issue. What then is "financial inclusion"? According to the World Bank, Financial inclusion means that individuals and businesses have access to useful and affordable financial products and services that meet their needs - transactions, payments, savings, credit and insurance - delivered in a responsible and sustainable

\section{3(1) BOFIA.}

29 Now Keystone Bank Plc. See Fatai, B.O., 'Can Islamic Banking Work in Nigeria?' Journal of Sustainable Development in Africa, vol. 14/2 (2012): 25

30 Habib Bank attempted to open a window of non-interest banking, but that commendable effort fell short of achieving continuity due to the absence of a legal framework. See Alkali, M.B., \& Buang, A.H., 'Challenges in Implementing Islamic Banking and Finance in Nigeria: A Legal Insight,' 146.

31 Sanusi, L.S., 'Islamic Finance in Nigeria: Issues and Challenges' (Lecture, the Markfield Institute of Higher Education (MIHE), Leicester, United Kingdom. June, 2011).

32 Aliyu, Shehu Usman Rano, 'Islamic Banking and Finance in Nigeria: Issues, Challenges and Opportunities,' MPRA: Munich Personal RePEc Archive, Paper No. 42573 (2012), 1-17. 
way. ${ }^{33}$ In a similar vein, financial inclusion also called "inclusive financing" is seen as the pursuit of making financial services accessible at affordable costs to all individuals and businesses, irrespective of net worth and size. ${ }^{34}$ It is, therefore, a process of ensuring access to appropriate financial products and services needed by vulnerable groups such as weaker sections and low-income groups at an affordable cost in a fair and transparent manner by mainstream institutional players. ${ }^{35}$ In this light, the Muslim population in Nigeria fits the description and a target of "appropriate" financial products.

Around two billion people don't use formal financial services and more than $50 \%$ of adults in the poorest households are unbanked, globally. ${ }^{36}$ In 2010 the results of a survey indicated that only 30.7 million out of the 85 million Nigerians above the age of eighteen had access to formal financial services, leaving out over 54 million either served by the informal institutions or totally unbanked. The formally banked (25.4 million) use the products and services of the deposit money banks either as salaried workers or for business. Additionally, Nigeria has a higher proportion of financially excluded adults among its African peers at 46.3 per cent, compared with 26.0 per cent in South Africa, 33.0 per cent in Botswana and 32.7 per cent in Kenya. ${ }^{37}$ In fact, another report suggested that there was a downward slide from 37 per cent in 2015 to 35 per cent in 2016, lagging behind the three other African countries surveyed. Data showed 69 per cent of Kenyans, 54 per cent of Tanzanians, and 40 per cent of Ugandans were financially included. ${ }^{38}$ In all these, the Northern region, with its substantial Muslim population, is further disadvantaged, with 68 per cent of adults excluded in both the North-East and North-West regions compared to the South-West region with 45 per cent! ${ }^{39}$ Although some writers attributed

33 The World Bank, 'Financial Inclusion,' http://www.worldbank.org/en/topic/ financialinclusion/overview, accessed on 15 August 2017.

34 Investopedia, 'Financial Inclusion', https:/www.investopedia.com/terms/f/ financial-inclusion.asp, accessed on 15 August 2017.

35 Joshi, D. P., 'Financial Inclusion and Financial Literacy' (Paper presented, OECD Bi-Seminar, Roundtable on the Updates on Financial Education and Inclusion Programmes, India, 28 June 2011).

36 The World Bank, 'Financial Inclusion.'

37 Enhancing Financial Innovation \& Access (EfinA), 'Access to Financial Services in Nigeria: 2010's Survey (2010).

38 Van de Walle, N., Wanga, C. Sahai, R., 'Why is Nigeria's Financial Inclusion Lagging Compared to Its African Peers?'

39 Bello, A., 'Islamic Banking Products and Challenges in Nigeria,' http:// saharareporters.com/2016/12/25/islamic-banking-products-and-challengesnigeria, accessed on 2 April 2018. 
this disparity to "insecurity and environmental pollution", ${ }^{40}$ a stronger factor is the prohibition of interest in Islam, the predominantly practised faith in these regions. ${ }^{41}$

To obviate this, the Central Bank of Nigeria collaborated with stakeholders to launch the National Financial Inclusion Strategy (NFIS) in 2012, aimed at further reducing the exclusion rate to $20 \%$ by 2020 . Its central objective was to get the number of adult Nigerians with access to payment services to increase from $21.6 \%$ in 2010 to $70 \%$ in 2020 , while those with access to savings should increase from $24.0 \%$ to $60 \%{ }^{42}$ Hence, a number of strategic measures were put in place; such as know-your-customer (KYC), agent banking framework, national financial literacy programme, cashless policy, mobile payment system, and establishing linkages between commercial banks, governments, and microfinance banks for funding micro, small and medium enterprises (MSMEs), as well as diverse credit enhancement schemes and programmes, among others. However, even with surveys showing that $30 \%$ of Muslims desire Shariah compliant financial products and another 50-60\% will use them if they are price competitive, ${ }^{43}$ the CBN strategy conspicuously left out the need to design unique policies favourable to the development of Islamic finance.

According to Dogarawa, exclusion due to religious belief has been a phenomenon among Muslims and he is of the view that Islamic banking has the potential to tap a large chunk of the savings and businesses belonging to Muslims and non- Muslims in the country who voluntarily exclude themselves from financial services due to religious and ethical reasons. ${ }^{44}$ Sanusi, in agreement, asserted that "Islamic finance has shown its potential in achieving financial inclusion in many economies by bringing in large under bank populations, especially Muslims into the urbanized financial

40 Aro-Gordon, S., 'Effectiveness of Financial Inclusion Strategy in Nigeria,' 16.

41 Sapovadia, V., 'Jaiz Bank, Nigeria: A Case Study on Non-interest Bank,' https:// mpra.ub.uni-muenchen.de/68763/, accessed on 15 March 2018. Dogarawa also posited that this largely as a result of religious considerations. See Bello, A., 'Islamic Banking Products and Challenges in Nigeria.'

42 Central Bank of Nigeria, 'Financial Inclusion', https://www.cbn.gov.ng/devfin/ fininc.asp, accessed on 15 March 2018.

43 Adeola, H., 'Islamic Finance: The Answer to Financial Inclusion in Nigeria,' (Paper presented, Enhancing Financial Innovation and Access (EFInA) Conference, 2009).

44 Dogarawa, as quoted in Bello, A., 'Islamic Banking Products and Challenges in Nigeria.' 
sector". ${ }^{45}$ Thus, greater financial inclusion is achieved when diverse economic activities, geographical regions and segments of the society have access to financial information, financial assistance, financial services of their choice and financing with ease and at minimum cost. This helps to promote balanced growth through its process of facilitating savings and investment and thus causing efficient resource allocation from the surplus sector of the society to deficit sectors of the society. ${ }^{46}$ It can also help reduce the overall gap in access to finance since non-Muslims are not prohibited from using Islamic financial services. $^{47}$

\section{LEGAL FRAMEWORK FOR ISLAMIC BANKING}

All the laws regulating banking in Nigeria, including the one enabling Islamic banking have their roots traceable to the Constitution. By virtue of item no. 6 of the Second Schedule of the Constitution of the Federal Republic of Nigeria, only the National Assembly is empowered to make laws regarding banks, banking, under the Exclusive Legislative List. Although the two ${ }^{48}$ principal legislations were enacted by the military as decrees in 1991, by virtue of section 315(4) (b) of the Constitution ${ }^{49}$ these laws have been ratified as if they were made by an Act of the National Assembly.

Opponents of Islamic banking hinge their argument on the provision of section 10 of the Nigerian Constitution, which provides that, "the Government of the Federation or a State shall not adopt any religion as State Religion"50 and that as such, the introduction of Islamic banking smacks of Islamising Nigeria. ${ }^{51}$ What they failed to do, however, is to demonstrate how this could be achieved through the introduction of Islamic financial services. Even the

45 Sanusi, L. S., 'Why Nigeria Needs Islamic Financing' (Paper Presented, Conference Global Financial Crisis, Abuja, 2013), 7.

46 Adigun, M. \& Kaura, U., 'Financial Inclusion in Nigeria: Issues and Challenges,' Occasional Paper, no. 45 (Abuja: Central Bank of Nigeria, 2013), 1-45.

47 Sapovadia, V., 'Jaiz Bank, Nigeria: A Case Study on Non-interest Bank,' 1.

48 BOFIA and CBNA.

49 The Constitution of the Federal Republic of Nigeria, 1999, as amended in 2011 (CFRN,1999).

50 The Constitution of the Federal Republic of Nigeria, 1999, as amended in 2011 (CFRN,1999).

51 Eyieyie, E., 'Islamic Banking, Law and Appropriate Regulation of NIFI in Nigeria,' The Guardian, 23 July 2011. 
Federal High Court in Sunday Ogboji vs. CBN and 2 others ${ }^{52}$ were tactical to have evaded this question when confronted with the plea to declare the licensing of the Jaiz Bank Plc. as tantamount to declaring Islam as a state religion and economic discrimination based on religion contrary to Sections 10 and 16 (1) (d) of the Constitution, as the argument was found to be absurd.

In a similar attempt, Agbede remarked that "in a country that professed to be secular, the Islamic law as a distinct third system is hardly compatible with the express provisions of the Constitution which prohibits any law that discriminates on grounds inter alia of religion." 53 This view is erroneous because Islamic banking does not preclude adherents of other faiths from participating. The only limitation is that all transactions involved must be halal. ${ }^{54}$ There is nothing wrong with this limitation considering that there are alternatives existing in conventional banking where there is no question as to what use monies are put to as long as the interest and the principal sum are paid back or renegotiated in the long run.

To the Muslim, the right to engage in a financial system compatible with his faith is beyond social and economic rights. It falls under Chapter IV of the Constitution as the right to freedom of religion. ${ }^{55}$ This right covers every aspect of the Muslim's life. As a fundamental human right, the government has an obligation to facilitate its actualization and the duty to put in place mechanisms to ensure it is not derogated upon except in the manner provided in Section 45(1) of the Constitution. ${ }^{56}$

Section 16 (1) (d) ${ }^{57}$ further cements this position by stating that, without prejudice to the right of Nigerians to participate in areas of the economy within the major sector of the economy, the government must protect the right of every citizen to engage in any economic activities outside the major sectors of the economy. It is the duty of the government to direct its policy towards ensuring the promotion of planned and balanced economic development ${ }^{58}$ in such a manner that wealth or the means of production and exchange is not concentrated

52 Godwin Sunday Ogboji v. Central Bank of Nigeria and 3 others (Unreported) suit No. FHC/ABJ/CS/710/2011.

53 See Agbede, I. O., 'The Legal Pluralism - the Symbiosis of Customary and Religious Laws: Problems and Prospects,' in Fundamentals of Nigerian Law, ed. Ajomo, M. A. (Ibadan: Spectrum Books, 1989), 238.

54 Halal is an Arabic word meaning lawful or permitted by Allah SWT.

55 See S. 38 (1), CFRN, 1999.

56 See S. 45 (1), CFRN, 1999.

57 CFRN, 1999.

58 16(2)(a) CFRN. 
in the hands of few individuals or a group..$^{59}$ This is exactly what the CBN actualised after decades of consultations. Thus, the Constitution clearly sets out to achieve an inclusive financial system where no one is prevented from participating in major sectors of the economy on any discriminatory grounds. Put differently, the conventional banking system does, in fact, discriminate against the millions of Muslims who feel strongly about the interest system it thrives on. So if there existed any unjust exclusion of adherents of any faith from the financial sector in general, it was achieved prior to the issuance of guidelines on Islamic banking.

\section{BANKS AND OTHER FINANCIAL INSTITUTIONS ACT}

It was the Banks and Other Financial Intuitions Decree (BOFID) of $1991^{60}$ which made a rather vague introduction of this profit loss sharing principle, but nothing tangible was done by the Central Bank of Nigeria (CBN) to issue any regulation until 2010. Even with that, strong opposition greeted the issuance of the regulations. The $\mathrm{CBN}$ issued the guidelines, branding Islamic banks as "non-interest financial institutions based on Islamic jurisprudence" and designated as "specialised banks" under section 66 of BOFIA. No sooner this was done, a legal practitioner rushed to the Federal High Court in Abuja to challenge CBN's powers to issue guidelines and sought for the de-licensing of Jaiz Bank Plc, the first bank to benefit from the regulation as a full-fledged financial institution operating under the Guidelines. ${ }^{61}$

It was argued that BOFIA did not contemplate that its provisions would be used to issue the guidelines on non-interest financial institutions operating under the principles of Islamic commercial jurisprudence. ${ }^{62}$ That when the CBN gave Jaiz International Bank Plc the license to operate in principle it was not for the bank to proceed as though it were licensed to operate as an "Islamic

$\overline{59} 16(2)(\mathrm{c}) \mathrm{CFRN}$.

60 The proviso in S. 23(1) made reference to the profit and loss sharing principle. Now Banks and Other Financial Institutions Act (BOFIA).

${ }^{61}$ Godwin Sunday Ogboji v. Central Bank of Nigeria and 3 others (Unreported) suit No. FHC/ABJ/CS/710/2011.

62 Eyieyie, E., 'The Central Bank of Nigeria, Islamic Banking, the Law and Appropriate Regulation of Non-Interest Financial Regulation in Nigeria,' Elombah News: A Nigerian Perpective of World Affairs, http://elombah.com/index.php/ articles/70-letters/7115-the-central-bank-of-nigeriaislamic-banking-the-law-andappropriate-regulation-of-non-interest-financial-institutions-in-nigeria-v15-7115 on 15 April 2017. 
bank" but as "profit and loss sharing bank". ${ }^{63}$ It is difficult to ignore the futility of this argument because whatever nomenclature it goes by, it is ipso facto Islamic banking. However, under Nigerian laws, an Islamic bank cannot be designated as "Islamic bank"; it is referred to as "non-interest financial institutions based on Islamic commercial jurisprudence." 64

However, it may appear that the CBN did not exhaustively consider the implication of its reliance on Section 66 of BOFIA. The provision defines "profit and loss sharing bank" to mean any bank which transacts investment or commercial banking business and maintains profit and loss sharing accounts. It is a well-established principle that promotes the concept of participation in a transaction backed by real assets, utilising the funds at risk on a profitand-loss-sharing basis, such as mushārakah and mudārabah. ${ }^{65}$ It is pretentious to suggest this was not why the principle was inserted in the Act. Besides when the decree was promulgated, the agitation for the introduction of laws to enable the operations of Islamic banking has a well-documented history in Nigeria. It was also the second decade after the first Islamic bank formally took off in Dubai. ${ }^{66}$ With prospects and seen to provide an alternative to the economic problems caused by the excessive reliance on conventional banks based on interest, ${ }^{67}$ and drive financial inclusion, it was in vogue then to make supportive laws for the operations of Islamic banking, the world over.

There is also an issue with section 52 of BOFIA, which confers on the Governor the power to exempt profit loss sharing banks from the provisions of the Act. ${ }^{68}$ The controversy is related to the abrogation of this provision. The section was inadvertently omitted in the laws of the Federation of Nigeria (LFN). It is pertinent to understand that Decree No.4 of 1997 which repealed this section was itself repealed by Decree No. 38 of 1998, effectively reversing the status quo. Section 57 also states that:

63 Eyieyie, E., 'The Central Bank of Nigeria, Islamic Banking, the Law and Appropriate Regulation of Non-Interest Financial Regulation in Nigeria.'

64 Section 39(1) of BOFIA.

65 Institute of Islamic Banking and Insurance, 'Islamic Banking,' http://www.islamicbanking.com/profit_and_lose_sharing.aspx, accessed on 3 March 2016.

66 Dubai Islamic Bank (DIB) created history in 1975 when it became the first modern commercial Islamic bank in the world. See World Finance: The Voice of the Market, 'Worlds First Islamic Bank Continues to Drive Industry,' https://www. worldfinance.com/banking/worlds-first-islamic-bank-continues-to-drive-industry, accessed on 12 March 2016.

67 Zubair, A. \& Alaro, A. A., 'Legal and Operational Frameworks of Islamic Windows in Conventional Financial Institutions: Nigeria as a Case Study.'

Section 52 BOFIA. 
"(1) The Governor may make regulations, published in the Federal Gazette(emphasised), to give full effect to the objects and objectives of this Act."

"(2) Without prejudice to the provisions of subsection (1) of this section, the Governor may make rules and regulations for the operations and control of all institutions under the supervision of the Bank."

Close scrutiny of the above provisions will reveal that there is no doubt that the $\mathrm{CBN}$ had the power to make regulations as empowered, what remains grey is whether the $\mathrm{CBN}$ has the power to introduce a system with no clear foundations in the law. Based on this, Shodipo argued that the CBN Act and BOFIA did not support the issuing out of the regulation of Islamic banking. That only the National Assembly can legislate on the matter. ${ }^{69}$ What was expected was for stakeholders to have rallied around to push for comprehensive legislation by the National Assembly in order to once and for all, give Islamic banking its deserved solid legal backing. The failure to do this inspired $\mathrm{Mr}$ Ogboji to take a case to the court insisting that unlike the other specialised banks, the Jaiz International Bank Plc could only have been established in the country with the intervention of the National Assembly by amending the law. ${ }^{70}$

No doubt the CBN proceeds under the argument that Islamic banking is captured under the provisions of section 66 of BOFIA, but the contention is where the power to so designate lies. The CBN appears to have conferred on itself the power to so designate by including non-interest banks in the category of specialised banks. ${ }^{71}$ The problem is, by the aid of the ejusdem generis rule of interpretation, regard must be had to the nature of the banks outlined in the provisions and the powers behind their establishment. Without exception, all the banks were established by different acts of the National Assembly. It is the reasoning of the presenter, that the $\mathrm{CBN}$ has a questionable basis for assuming the power to categorise non-interest banks as specialised banks. Thus, only those banks established by the National Assembly can conceivably fall under the protection of section 66 of BOFIA. The effect of this, therefore, is that all

69 Yusuf, I. A., 'Much Ado About Islamic banking,' The Nation, 26 June 2011. See also Abikan, A. I., 'Constitutionality of Islamic Banking in Nigeria,' in Contemporary Issues in Islamic Jurisprudence (Benin: Rawel Fortune Resources, 2009), 94-121, Chapter 7.

70 Eyieyie, E., 'The Central Bank of Nigeria, Islamic Banking, the Law and Appropriate Regulation of Non-Interest Financial Regulation in Nigeria.'

71 Section 4(1) (c) of the Central Bank of Nigeria, Regulation and Scope of Banking Activities and Ancillary Matters, No. 3, 2010. 
the regulations made on the shaky ground that non-interest banks fall under the category of specialised banks have questionable validity. The argument that the CBN is acting on the powers vested in it under the principle of delegated legislation $^{72}$ leaves more room for questions and opens the door for more confusion. If it were the intention of the drafters to so designate Islamic banks as specialised institutions, the Act would have been explicit about it as it did with the definition of "other financial institutions" in section 66 of BOFIA, by conferring the powers to so designate on the CBN. ${ }^{73}$

When the then CBN governor challenged aggrieved persons to head to court, he never envisaged a certain Ogboji will appear before a justice Kolawale to threaten the existence of Islamic banking. The idea to establish Islamic banking was perfected by Soludo. ${ }^{74}$ This did not stop the Federal High Court in declaring the operation of Islamic banking in Nigeria unlawful and inconsistent with the provisions of the CBN Act and the BOFIA. It was declared that any operation license granted by the $\mathrm{CBN}$ to any Islamic commercial jurisprudence bank under the non-interest financial services was illegal, unlawful, ultra vires, null and void. The Judge argued that the CBN does not have the power to designate Islamic banks as specialised bank and that the Constitution says the government should not adopt any religion. Though Jazz International bank did not have its license revoked by the court, the ruling pointed out that the future of Islamic banking in Nigeria could be challenged further.

\section{NON-INTEREST FINANCIAL INSTITUTIONS REGULATION}

In March 2009, the Banking Supervision Department of the CBN released an exposure draft of the framework for the regulation and supervision of non-interest banks in Nigeria for comments, suggestions and inputs from stakeholders. The CBN created a unit under the banking supervision department for effective supervision of the NIFIs. ${ }^{75}$ In August 2010, The CBN released the new banking model which designated non-interest banks among the specialised banks. ${ }^{76}$ The Guidelines has the clear objective of providing

72 Olayemi, A. A. M., 'The Legality of Islamic Banking in Nigeria: A Critical Approach,' https://papers.ssrn.com/sol3/papers.cfm?abstract_id=1941010\&rec $=1$ $\&$ srcabs $=2166538 \&$ alg $=1 \&$ pos $=3$, accessed on 18 October 2015 .

73 S. 66 BOFIA.

74 Soludo approved in October 2008 a system set in motion in 1991.

75 Aliyu, Shehu Usman Rano, 'Islamic Banking and Finance in Nigeria: Issues, Challenges and Opportunities,' 8.

76 Section 4(1) (c) of the Central Bank of Nigeria, Regulation and Scope of Banking Activities and Ancillary Matters, No. 3, 2010. 
minimum standards for the operation of institutions offering Islamic financial services in Nigeria and does not pretend to regulate other forms of non-interest financial institutions that may be established by the CBN. ${ }^{77}$

Accordingly, NIFIs include the following: (i) Full-fledged Islamic bank or full-fledged Islamic banking subsidiary of a conventional bank; (ii) Fullfledged Islamic merchant or full-fledged Islamic banking subsidiary of a conventional merchant bank; (iii) Full-fledged Islamic microfinance bank; (iv) Islamic branch or window of a conventional bank; (v) Islamic subsidiary, branch or window of a non-bank financial institution; (vi) A development bank regulated by the $\mathrm{CBN}$ offering Islamic financial services; (vii) A primary mortgage institution licensed by the $\mathrm{CBN}$ to offer Islamic financial services either full-fledged or as a subsidiary; and (viii) A finance company licensed by the $\mathrm{CBN}$ to provide financial services either full-fledged or as a subsidiary. ${ }^{78}$

The full-fledged non-interest banks are categorised into two. The first is national non-interest bank, which shall have a capital base of N10 billion and will operate in every state of the Federation including the Federal Capital Territory (FCT) ${ }^{79}$ Regional non-interest bank, which shall have a capital base of $\mathrm{N} 5$ billion, and will operate in a minimum of six states and a maximum of 12 contiguous states of the Federation, lying within not more than two geopolitical zones as well as the within the Federal Capital Territory. ${ }^{80}$ It also prohibited interest, uncertainty or ambiguity relating to the subject matter, terms or conditions; gambling, speculation, unjust enrichment, exploitation/ unfair trade practices, dealings in pork, alcohol, arms and ammunition, pornography and, other transactions, products, goods or services which are not compliant with Shariah rules and principles. ${ }^{81}$ The Modes of financing

77 S. 2 Framework for the Regulation and Supervision of Institutions Offering NonInterest Financial Services in Nigeria, FPR/DIR/CIR/GEN/01/010, January 13, 2011.

78 S. 2 Framework for the Regulation and Supervision of Institutions Offering NonInterest Financial Services in Nigeria, FPR/DIR/CIR/GEN/01/010, January 13, 2011.

79 S. 4(4) Framework for the Regulation and Supervision of Institutions Offering Non-Interest Financial Services in Nigeria, FPR/DIR/CIR/GEN/01/010, January 13, 2011.

80 S. 4(3) Framework for the Regulation and Supervision of Institutions Offering Non-Interest Financial Services in Nigeria, FPR/DIR/CIR/GEN/01/010, January 13, 2011.

81 S. 1.(0) Framework for the Regulation and Supervision of Institutions Offering Non-Interest Financial Services in Nigeria, FPR/DIR/CIR/GEN/01/010, January 13, 2011. 
permitted are as follows: muḍ̄arabah, murābahah, mushārakah, ijārah, ijārah wa iqtina, salam, istișnā', șukūk, wakālah, and waḍ̄'ah.

This guideline was, however, criticised as simply redefining non-interest institutions as Islamic banking contrary to the letter of the Banks and Other Financial Institutions Act "ostensibly in the mistaken belief that only Muslims are interested in that form of financial service". ${ }^{82} \mathrm{Mr}$ Ogboji ${ }^{83}$ on his part contended that the $\mathrm{CBN}$ and its governor acted ultra vires by issuing guidelines, not in their power to make, as well as granting a license without ministerial approval. Essentially, he challenged the CBN governor's power to validly issue guidelines for the regulation of banking operation in respect to NIFIs because that is not expressly provided for by BOFIA, and also that the governor failed to comply with the provisions of S. 3(5) of the Act. Although, the defendants argued that the position of the law had changed with amendments over the years and the CBN had been restored with its autonomy and independence, and there was, therefore, no need any longer for ministerial approval, the Judge still disregarded the contention and shifted the judicial responsibility of combined interpretation of the law to the National Assembly, thereby sustaining the argument of the plaintiff. With due respect to the learned judge, this was done in error.

BOFIA was indeed amended by Decree No. 25 of 1997, Decree No. 38 of 1998 and the Decree No 40 of 1999. It was Decree No. 25 that introduced the ministerial approval, but the latter decrees ${ }^{84}$ reversed the situation. However, the omission of this reversed position was to be put right by the revised edition, ${ }^{85}$ which categorically stated that any "inadvertent omission, alteration or amendment of any existing statute shall not affect the validity and application of the statute" ${ }^{86}$ There was, therefore, no requirement for ministerial approval as at the time the license was granted to Jaiz Bank.

Nigeria, being a secular country does not preclude anyone from practising Islamic banking as long as those tenets and principles are ready to be complied with. ${ }^{87}$ Moreover, the CBN Guidelines expressly states that any individual

\footnotetext{
82 Eyieyie, E., 'The Central Bank of Nigeria, Islamic Banking, the Law and Appropriate Regulation of Non-Interest Financial Regulation in Nigeria.'

83 Sunday Ogboji vs. CBN and 2 others (supra)

84 Particularly, Section 45 of the Amendment to the Banks and Other Financial Institutions Decree No 38 of 1998

85 Laws of the Federation of Nigeria, 2007.

86 Laws of the Federation of Nigeria, 2007.

87 Fakiyesi, T., 'Islamic Banking and the Nigerian Financial System' (Paper Presented, Round-Table Workshop at Nigeria Institute of Advanced Legal Studies, University of Lagos, Akoka-Yaba, 6 June, 2011).
} 
or group wishing to put forward its own system of banking may approach it to work out its own guidelines, and call it whatever name they so wish. The Prophet (SAW) himself engaged in various financial relations with Christians and Jews. Moreover, the law expressly prohibits the exclusion of non-Muslims. ${ }^{88}$ In addition, the guideline, in promoting financial inclusion in Nigeria, categorically states that "guidelines for other categories of noninterest banking will be issued upon request which shall be consistent with international best practice". ${ }^{89}$ Individuals and groups not satisfied with the guidelines issued under Islamic commercial law jurisprudence may as well apply to the $\mathrm{CBN}$ to issue guidelines under established rules they choose to subscribe to.

\section{THE PROSPECTS OF ISLAMIC BANKING IN NIGERIA}

Islamic banking is going from an attempt by the Muslim World to exert influence on the global financial space for imperialistic reasons,${ }^{90}$ to a rational solution to the often out of control financial system bedevilled by immoral exploitations and crises. ${ }^{91}$ Uganda recently passed national legislation backing the operations of Islamic banking, ${ }^{92}$ while countries like Germany, ${ }^{93}$ United

88 Section 16(2) Framework for the Regulation and Supervision of Institutions Offering Non-Interest Financial Services in Nigeria.

89 Preamble, Framework for the Regulation and Supervision of Institutions Offering Non-Interest Financial Services in Nigeria.

90 Pollard, J. \& Samers, M., 'Islamic Banking and Finance: Postcolonial Political Economy and the Decentring of Economic Geography,' Transactions of the Institute of British Geographers, vol. 32 (2007): 313-330.

91 The 2008 global meltdown was largely attributed to the greed of those in control of the global financial system. While other models were crumbling with it, the Islamic model appreciated. See IMF, 'Global economic crisis, islamic banks: more resilient to crisis?' IMF Survey Online, https://www.imf.org/en/News/ Articles/2015/09/28/04/53/sores100410a, accessed on 27 October 2017.

92 allAfrica, 'Uganda Finalizes Islamic Banking Regulations', East Africa Business Week, https://allafrica.com/stories/201706050215.html, accessed on 1 June 2017.

93 RT Question More, 'Germany's first interest-free Islamic bank opens in Frankfurt', https://www.rt.com/business/271105-germany-opens-islamic-bank/, accessed on 3 March 2016. 
Kingdom ${ }^{94}$ and many other non-Muslim dominated countries have since enacted different forms of legislation aiding the seamless establishment and operations of Islamic banks, products and services. It was the potential of Islamic banking that prompted the International Monetary Fund (IMF) to facilitate the establishment of the Islamic Financial Services Board (IFSB), the Islamic equivalent of IMF in 2002, the idea is addressing the need for a suitable regulatory framework, new financial instruments and institutional arrangements for Islamic finance operations. ${ }^{95}$

Conventional banking has not really worked in the best interest of Nigerians, especially in securing loans for investments. In fact, it's over-reliance on interest, ${ }^{96}$ loose prudential guidelines and its general capitalistic foundations have brought it into collision with the Islamic and customary principles of communality as against individuality known in Nigeria. Securing loans for investments comes with cut-throat conditions, riddled with cases of fraudulent and sharp practices that significantly erode of the customers. ${ }^{97}$ Islamic finance, on the other hand, promotes economic growth through its developmental and social benefit focus and more equitable contracts. It also presents an opportunity to harness the money held outside the financial system due to the avoidance of interest and serves as a major factor required to bridge the access to finance gap in Nigeria. ${ }^{98}$ For Nigeria's financial inclusion strategy to remain

94 Islamic Finance first came to the UK in the 1980s, with the introduction of murābahah transactions. The first UK Islamic bank, Al Baraka International, launched in 1982. This was followed by the growth of bespoke Sharia-compliant products in trade finance, leasing and project finance. See British Embassy Bishkek, Islamic Finance in the UK (Bishkek: British Embassy Bishkek, n.d.), 4.

95 Khan, H. \& Bashar, O. K. M. R., 'Islamic Finance: Growth and Prospects in Singapore,' U21 Global Working Paper Series, no. 1 (2008).

96 Prohibitive double digit interest rates discourage many investors. The average Prime lending rates stand at $17.3 \%$. See https://www.cbn.gov.ng/rates/mnymktind. asp. Lending interest rate (\%) in Nigeria as at 2014 was 16.55 . Over the past 44 years, the value for this indicator has fluctuated between 31.65 in 1993 and 6.00 in 1977. See Index Mundi, 'Nigeria - Lending interest rate', https://www. indexmundi.com/facts/nigeria/lending-interest-rate, accessed on 16 August 2017.

97 Alao, D. O. \& Alao, E. M., 'Islamic Banking: The Controversy over Non-Interest Banking System in Nigeria,' Arabian Journal of Business and Management Review, vol. 1/1 (2012): 2.

98 Adewusi, Y., 'Non-interest Banking and Financial Inclusion,' (Paper presented, International Conference on Non-Interest Banking, organized by the Central Bank of Nigeria in Collaboration with the Islamic Development Bank (IDB), Jeddah, held at Transcop Hotel, Abuja, Nigeria on 4th July, 2011). 
effective towards national aspirations of poverty eradication, financial stability and sustainable development, financial inclusion intervention measures should be expeditiously and continuously identified and provided as a smart way to diversify the economy. ${ }^{99}$ Looking at the global base and potentials of Islamic banking, the $\mathrm{CBN}$ must commit more resources to position Islamic banks to succeed in the quest for financial inclusion.

Today, Nigerians are participating at different levels. Some as investors, others maintain accounts and are funding their franchises with capital from Islamic banks. When Jaiz Bank was established, there were 60 Christian shareholders, and one of the owners of substantial shares in the bank is an Igbo Christian. ${ }^{100}$ Islamic banking has grown steadily over the years. Its popularity has been appreciating with the increasing failure rate of conventional banks. In 2005 , Islamic Banking was growing at a rate of $10-15 \%$ per year. The growth went up to about $20 \%$ in 2008 . It was further estimated that the industry will grow at a rate of 15 to 20 per cent annually, from assets of US\$300 billion. ${ }^{101}$ Expected growth in 2013 was put at 24\%. Islamic banks now operate in many Muslim and non-Muslim countries including the United States through companies such as the Michigan based University Bank, Kenya and South Africa. ${ }^{102}$

In 2008 the capital base of Islamic banks was $\$ 850$ billion globally, and it grew geometrically to an estimated $\$ 1.6$ trillion in 2013. In 2008, according to an IMF study, Islamic banks fared better than most of their conventional counterparts in terms of profitability, credit and asset growth than their conventional counterparts. ${ }^{103}$ This was also replicated by $2010 .{ }^{104}$ Global financial institutions are leveraging on this growing and interesting market. HSBC, Citigroup, Deutsche Bank, Standard Chartered Bank, Barclays Capital, ABN Amro. It was projected that Islamic Banking will be increased to 10 per cent from 2.5 per cent in Pakistan, from 13 to 20 per cent in Malaysia, 3

$99 \quad$ Aro-Gordon, S., 'Effectiveness of Financial Inclusion Strategy in Nigeria,' 16.

100 The Nigeria, 'CBN clarifies on Igbo's holding 60\% Islamic Bank Shares', http:// thenigeria.com/index.php?option $=$ com_content $\& v i e w=$ article $\& i d=316: \mathrm{cbn}-$ clarifies-on-igbos-holding-60-islamic-bank-shares \&catid=2:userarticles\&Itemid=3, accessed on 23 March 2015.

101 Al-Salem, F., 'The Size and Scope of the Islamic Finance Industry: An Analysis,' International Journal of Management (2008): 124-130.

102 Yekini, O. L., 'Islamic Economics the Connerstone of Islamic Banking,' Journal of Economics and Engineering, vol. 4 (2010): 72.

103 IMF, 'Global economic crisis, islamic banks: more resilient to crisis?'

104 Aliyu, Shehu Usman Rano, 'Islamic Banking and Finance in Nigeria: Issues, Challenges and Opportunities,' 12. 
per cent to 10 per cent in Indonesia and 60 per cent in the Gulf Cooperation Council (GCC) countries. ${ }^{105}$

Some of those opposing Islamic banking feared that Jaiz Bank could promote the activities of Boko Haram. ${ }^{106}$ However, this fear has been proven to be unfounded. Jaiz bank has been in operation for about eight years now and no evidence that Boko Haram activities have been facilitated remotely or indirectly by the existence of such bank. Indeed, more non-Muslims have discovered the true potentials of Islamic banking and have endorsed it or are participating in its activities. ${ }^{107}$ The trend is by now clear that the Islamic financial system brings forth goodies worth tapping into by every serious economy, with Nigeria's economy just limping out of recession. Islamic banks have generally the highest rate of capital adequacy ratio (CAR). From 2012 to 2014 Jaiz bank had its CAR above 70\% when other conventional banks were struggling to keep it between $10 \%$ and at a maximum of $35 \% .{ }^{108}$ Jaiz bank has no doubt taken the lead and has become fairly successful, dislodging some of the arguments of the opposition to Islamic banking. It has financed businesses across Nigeria including the purchase of aircraft in the aviation sector under the principle of ijarah wa iqtina. ${ }^{109}$ In 2014 it announced a whopping 380\% growth in investments from N1.9billion to N9.4billion. Customer deposits also grew by $460 \%$ - from N3.2billion to N18.6billion, and profitability grew by $750 \%$. The bank started with only three branches in Kano, Kaduna and Abuja

${ }_{105}$ Memon, N. A., 'Islamic Banking: Present and Future Challenges,' Journal of Management and Social Sciences, vol. 3/1 (2007): 1-10.

106 Nigerian Supreme Council of Islamic Affairs, 'Islamic Banking in Nigeria: Need for Understanding, Objectivity and Tolerance,' The Sun, 29 August 2011.

107 Kayongo, P.M., 'Islamic banking can succeed in largely Christian society,' http:// www.monitor.co.ug/OpEd/Commentary/Islamic-banking-can-succeed-in-largelyChristian-society/689364-4007490-kkohk9z/index.html, accessed on 15 October 2017.

108 Islamic Financial Services Board (IFSB), 'Islamic Financial Services Industry Stability Report 2014', http://www.ifsb.org/docs/2014-05-06_IFSI\%20 Stability\%20Report\%202014\%20(Final).pdf, accessed on 3 March $201 \overline{6}$.

109 As a mode of financing by way of hire-purchase, adopted by Islamic banks but different from conventional hire-purchase. Under the agreement an Islamic bank purchases an asset such as an equipment giving it on lease against payment of agreed rentals together with an undertaking or promise that the ownership will be transferred to the lessee; the undertaking or promise does not become part of the lease contract to make it conditional. Ownership is transferred through a separate contract of sale or gift. See Institute of Islamic Banking and Insurance, 'Glossary of Financial Terms', http://www.islamic-banking.com/glossary_i.aspx, accessed on 19 December 2016. 
in 2012, but has now had over 18 branches so far, with the target of opening 16 more before the end of 2015. Meanwhile, having surpassed the capital requirement for national operations, the bank applied for a national operating license and secured it in $2016 .^{110}$

\section{CONCLUSION}

The principles guiding Islamic banking are not new, what is recent is their infusion into modern conventional banking. The Islamic financial system offers a reliable alternative to the conventional mode of financial intermediation globally. There is no pretending that Muslims are the only section hit by financial exclusion, but it is clear that they are most hit by it. Previous researches have either ignored or disregarded the implications of the express prohibition of interest in Islam, the reluctance of participation in the conventional banking system by Muslims. It has indeed been proved that there is a strong correlation between the two. The promotion of Islamic banking and finance may not be the only way to overcome the embarrassing side of financial exclusion in Nigeria, but it sure will go a long way in addressing some aspect of it.

The flip side of financial inclusivity is exclusivity. No reasonable law, policy or system should deliberately shut out any section of its population from participating in the financial spectrum. It is the responsibility of those responsible for designing the financial system to fashion out laws and policies in order to shove up the inclusion of all Nigerians in the financial sub-sector of the economy. Provision of a level playing field to conduct businesses and engage in gainful economic activities is a duty on the government. The opposition to Islamic banking is unfounded and not based on any rational economic theory. It is in fact, systematic validation of financial exclusion of a substantial number of Nigerians from the financial stream. It should be seen an opportunity to mobilize savings - resources for the ultimate benefit of the economy, rather than an attempt to institutionalize the dominance of Muslims - a group empirically proved to be at the disadvantage. Indeed, there is yet any evidence linking Islamic banking to any act of imperialism, religious dominance or imposition on anybody.

As Nigeria is trying to push for financial inclusion, the government must give equal attention to every sector of the economy. Every viable venture deserves support from the government. This is particularly so as it appears to be thriving through its piloting by Jaiz Bank Plc. Islamic banking can

110 Jaiz Bank Plc, ‘About Jaiz Bank', http://jaizbankplc.com/about-jaiz/, accessed on 18 April 2017. 
help refine existing credit delivery mechanisms, strengthen credit absorption capacities, and serve as a model for effective outreach to the teeming excluded population of Muslims exhibiting reservations towards conventional banking.

The legal framework for Islamic banking is rather incoherent and in some cases, vague. The laws do not contemplate the fundamental conditions required for Islamic banking to thrive, as they have been originally designed to suit conventional banking. What will be required is comprehensive legislation by the National Assembly to address this concern, and to also put to rest the recurring assault on the guidelines issued by the $\mathrm{CBN}$ on Islamic banking. This is what obtains in countries like Malaysia, United Arab Emirates, Germany and Uganda.

The CBN can also de-emphasise the operations of these banks as "specialised banks". This will enable this system to thrive under the principle of "profit loss sharing", which has express legal support in the BOFIA. However, this option will still leave room for controversies largely on the ground that these provisions were not intended to be narrowed down to the establishment of Shariah compliant system.

Similarly, policy initiatives to promote financial inclusion through Islamic finance seem half-hearted in design and overly cautious in implementation. The CBN financial inclusion strategy does not take into account the potentials Islamic finance holds in Nigeria and how it can shove up financial inclusion especially in the Northern part of the country, more than any other strategy. There is the need to embark on an aggressive campaign, by all stakeholders, to support Jaiz Bank and any other bank willing to exploit the principles of Islamic finance to drive financial inclusion.

\section{REFERENCES}

Abikan, A. I., 'Constitutionality of Islamic Banking in Nigeria,' in Contemporary Issues in Islamic Jurisprudence (Benin: Rawel Fortune Resources, 2009), 94-121, Chapter 7.

Adeola, H., 'Islamic Finance: The Answer to Financial Inclusion in Nigeria,' (Paper presented, Enhancing Financial Innovation and Access (EFInA) Conference, 2009).

Adewusi, Y., 'Non-interest Banking and Financial Inclusion,' (Paper presented, International Conference on Non-Interest Banking, organized by the Central Bank of Nigeria in Collaboration with the Islamic Development Bank (IDB), Jeddah, held at Transcop Hotel, Abuja, Nigeria on 4th July, 2011). 
Adigun, M. \& Kaura, U., 'Financial Inclusion in Nigeria: Issues and Challenges,' Occasional Paper, no. 45 (Abuja: Central Bank of Nigeria, 2013), 1-45.

Agbede, I. O., 'The Legal Pluralism - the Symbiosis of Customary and Religious Laws: Problems and Prospects,' in Fundamentals of Nigerian Law, ed. Ajomo, M. A. (Ibadan: Spectrum Books, 1989).

Ahmad, A., Kashif-ur-Rehman \& Humayoun A. A., 'Islamic Banking and Prohibition of Riba/Interest,' African Journal of Business Management, vol. 5/5 (2011): 1763-1767.

Ahmad, A.R.Y., 'Riba, Its Economic Rationale and Implications,' Institute of Islamic Banking and Insurance, Islamic University Pakistan, http:// www.islamic-banking.com/iarticles_8.aspx, accessed on 5 March 2018.

Ajagbe, T. S. \& Brimah, A. N., 'Islamic Banking Development and Evolution: Current Issues and Future Prospects,' Journal of Research in International Business and Management, vol. 3/2 (2013): 73-79.

Alao, D. O. \& Alao, E. M., 'Islamic Banking: The Controversy over NonInterest Banking System in Nigeria,' Arabian Journal of Business and Management Review, vol. 1/1 (2012): 65-78.

Aliyu, Shehu Usman Rano, 'Islamic Banking and Finance in Nigeria: Issues, Challenges and Opportunities,' MPRA: Munich Personal RePEc Archive, Paper No. 42573 (2012), 1-17.

Al-Haidar, F., 'Whistleblowing in Kuwait and UK against Corruption and Misconduct,' Journal of Law and Management (2017): 4-17.

Alharbi, A., 'Development of the Islamic Banking System,' Journal of Islamic Banking and Finance, vol. 3/1 (2015): 12-25.

Ali, S. S., Modern Challenges to Islamic Banking (Cambridge: Cambridge University Press, 2016).

Alkali, M.B., \& Buang, A.H., 'Challenges in Implementing Islamic Banking and Finance in Nigeria: A Legal Insight,'Jurnal Syariah, vol. 23/1 (2015): 141-166.

allAfrica, 'Uganda Finalizes Islamic Banking Regulations', East Africa Business Week, https://allafrica.com/stories/201706050215.html, accessed on 1 June 2017.

Al-Salem, F., 'The Size and Scope of the Islamic Finance Industry: An Analysis,' International Journal of Management (2008): 124-130. 
Aro-Gordon, S., 'Effectiveness of Financial Inclusion Strategy in Nigeria', (Paper presented, 2nd International Conference on Inclusive Economic Growth and Sustainable Development, Mysuru, India, 18-19 November 2016).

Beck, T. \& Brown, M., 'Which Households Use Banks? Evidence from the Transition Economies,' European Central Bank Working Paper Series, No. 1295 (2011): 4-32.

Bello, A., 'Islamic Banking Products and Challenges in Nigeria,' http:// saharareporters.com/2016/12/25/islamic-banking-products-andchallenges-nigeria, accessed on 2 April 2018.

British Embassy Bishkek, Islamic Finance in the UK (Bishkek: British Embassy Bishkek, n.d.).

Central Bank of Nigeria, 'Financial Inclusion', https:/www.cbn.gov.ng/ devfin/fininc.asp, accessed on 15 March 2018.

Chiroma, M. \& Sandabe K.B, Abdullahi, M.A. \& Haseeb A., 'Legal Framework Regulating Islamic Finance in Nigeria: A Critical Appraisal of Hurdles against the Effective Shari'ah Governance,' Unimaid Journal of Private and Property Law, vol. 1/1 (2016): 245-253.

Demirgic-Kunt, A., Klapper, L. \& Randall, D., 'Islamic Finance and Financial Inclusion: Measuring use of and Demand for Formal Financial Services among Muslim Adults,' The World Bank Policy Research Working Paper 6642 (2013): 1-43.

Enhancing Financial Innovation \& Access (EfinA), 'Access to Financial Services In Nigeria: 2010's Survey (2010), www.EfinA.org.ng, accessed on 12 February 2018.

Eyieyie, E., 'Islamic Banking, Law and Appropriate Regulation of NIFI in Nigeria,' The Guardian, 23 July 2011.

Eyieyie, E., 'The Central Bank of Nigeria, Islamic Banking, the Law and Appropriate Regulation of Non-Interest Financial Regulation in Nigeria,' Elombah News: A Nigerian Perpective of World Affairs, http:// elombah.com/index.php/articles/70-letters/7115-the-central-bank-ofnigeriaislamic-banking-the-law-and-appropriate-regulation-of-noninterest-financial-institutions-in-nigeria-v15-7115 on 15 April 2017.

Fakiyesi, T., 'Islamic Banking and the Nigerian Financial System' (Paper Presented, Round-Table Workshop at Nigeria Institute of Advanced Legal Studies, University of Lagos, Akoka-Yaba, 6 June, 2011). 
IMF, ‘Globaleconomic crisis, islamic banks: moreresilient to crisis?' IMF Survey Online, https://www.imf.org/en/News/Articles/2015/09/28/04/53/ sores 100410a, accessed on 27 October 2017.

Index Mundi, 'Nigeria - Lending interest rate', https://www.indexmundi.com/ facts/nigeria/lending-interest-rate, accessed on 16 August 2017.

Institute of Islamic Banking and Insurance, 'Glossary of Financial Terms', http://www.islamic-banking.com/glossary_i.aspx, accessed on 19 December 2016.

Institute of Islamic Banking and Insurance, 'Islamic Banking,' http://www. islamic-banking.com/profit_and_lose_sharing.aspx, accessed on 3 March 2016.

Investopedia, 'Financial Inclusion', https://www.investopedia.com/terms/f/ financial-inclusion.asp, accessed on 15 August 2017.

Islamic Financial Services Board (IFSB), 'Islamic Financial Services Industry Stability Report 2014', http://www.ifsb.org/docs/2014-05-06_IFSI\%20 Stability\%20Report\%202014\%20(Final).pdf, accessed on 3 March 2016.

Jaiz Bank Plc, ‘About Jaiz Bank’, http://jaizbankplc.com/about-jaiz/, accessed on 18 April 2017.

Joshi, D. P., 'Financial Inclusion and Financial Literacy' (Paper presented, OECD Bi-Seminar, Roundtable on the Updates on Financial Education and Inclusion Programmes, India, 28 June 2011).

Kayongo, P.M., 'Islamic banking can succeed in largely Christian society,' http://www.monitor.co.ug/OpEd/Commentary/Islamic-banking-cansucceed-in-largely-Christian-society/689364-4007490-kkohk9z/index. html, accessed on 15 October 2017.

Khan, H. \& Bashar, O. K. M. R., 'Islamic Finance: Growth and Prospects in Singapore,' U21 Global Working Paper Series, no. 1 (2008).

Memon, N. A., 'Islamic Banking: Present and Future Challenges,' Journal of Management and Social Sciences, vol. 3/1 (2007): 1-10.

National Population Commission (NPC), 'Nigeria's current population is put at 198 million people', http://population.gov.ng/, accessed on 16 March 2018.

Olayemi, A. A. M., 'The Legality of Islamic Banking in Nigeria: A Critical Approach,' https://papers.ssrn.com/sol3/papers.cfm?abstract_id=1941 $010 \&$ rec $=1 \&$ srcabs $=2166538 \&$ alg $=1 \&$ pos $=3$, accessed on 18 October 2015. 
Oyeniran, B., 'Can Islamic Banking Work in Nigeria?' Journal of Sustainable Development in Africa, vol. 14/2 (2012): 25.

Pollard, J. \& Samers, M., 'Islamic Banking and Finance: Postcolonial Political Economy and the Decentring of Economic Geography,' Transactions of the Institute of British Geographers, vol. 32 (2007): 313-330.

RT Question More, 'Germany's first interest-free Islamic bank opens in Frankfurt', https://www.rt.com/business/271105-germany-opensislamic-bank/, accessed on 3 March 2016.

Sanusi, L. S., 'Why Nigeria Needs Islamic Financing' (Paper Presented, Conference Global Financial Crisis, Abuja, 2013).

Sanusi, L.S., 'Islamic Finance in Nigeria: Issues and Challenges' (Lecture, the Markfield Institute of Higher Education (MIHE), Leicester, United Kingdom. June, 2011).

Sapovadia, V., 'Jaiz Bank, Nigeria: A Case Study on Non-interest Bank,' https://mpra.ub.uni-muenchen.de/68763/, accessed on 15 March 2018.

Siddiqi, M.J., 'Issues in Islamic Banking,' Economic Series, vol. 4 (Leicester, Islamic Foundation, 1983).

The Nigeria, 'CBN clarifies on Igbo's holding 60\% Islamic Bank Shares', http://thenigeria.com/index.php?option=com content\&view =article \&id=316:cbn-clarifies-on-igbos-holding-60islamic-bank-shares\&catid=2:user-articles\&Itemid $=3$, accessed on 23 March 2015.

The World Bank, 'Financial Inclusion,' http://www.worldbank.org/en/topic/ financialinclusion/overview, accessed on 15 August 2017.

Van de Walle, N., Wanga, C. Sahai, R., 'Why is Nigeria's Financial Inclusion Lagging Compared to Its African Peers?,' http://finclusion.org/blog/fiiupdates/why-is-nigerias-financial-inclusion-lagging-compared-to-itsafrican-peers.html, accessed on 3 February 2018.

World Finance: The Voice of the Market, 'Worlds First Islamic Bank Continues to Drive Industry,' https://www.worldfinance.com/banking/worlds-firstislamic-bank-continues-to-drive-industry, accessed on 12 March 2016.

Yekini, O. L., 'Islamic Economics the Connerstone of Islamic Banking,' Journal of Economics and Engineering, vol. 4 (2010).

Yusuf, I. A., 'Much Ado About Islamic banking,' The Nation, 26 June 2011. 
Zubair, A. \& Alaro, A. A., 'Legal and Operational Frameworks of Islamic Windows in Conventional Financial Institutions: Nigeria as a Case Study,' (Paper presented, 1st University of Ilorin International Conference on Islamic Bank and Finance, Jointly Organized by Department of Islamic Law, UNILORIN and Islamic Research and Training Institute, Jeddah, Saudi-Arabia, 6-8 October 2009).

\section{Statutes}

Banks and Other Financial Institutions Act (BOFIA)

Banks and Other Financial Institutions Decree No 38 of 1998.

Laws of the Federation of Nigeria (LFN), 2007.

Section 4(1) (c) of the Central Bank of Nigeria, Regulation and Scope of Banking Activities and Ancillary Matters, No. 3, 2010.

The Constitution of the Federal Republic of Nigeria, (1999). As amended in2011 (CFRN,1999)

\section{Cases}

Godwin Sunday Ogboji v. Central Bank of Nigeria and 3 others (Unreported) suit No. FHC/ABJ/CS/710/2011. 
Jurnal Syariah, Jil. 28, Bil. 3 (2020) 501-530 